\title{
Türkiye 'de Yerel Yönetimlerin Güncel Kentsel Sorunlara Yaklaşımı
}

\author{
DOI: $10.26466 /$ opus.669211
}

$*$

\author{
Murat Sezik* \\ * Dr.Öğr. Üyesi İnönü Üniversitesi İ.İ.B.F. Siyaset Bilimi ve Kamu Yönetimi Bölümü \\ E-Posta: $\underline{\text { murat.sezik@inonu.edu.tr }}$ \\ ORCID: 0000-0001-6219-1859
}

\section{Öz}

Demokratik ülkelerde yerel yönetimler, yönetim yapısı içerisinde her zaman önemli bir yere sahip olmuştur. Yerel yönetim organlarının seçimle iş başına gelmesi, kenti temsil eden meclislere sahip olmaları ve çeşitli siyasal katılım kanallarını açı tutmaları onları demokrasi için vazgeçilmez kılmıştır. Bu kurumlar aynı zamanda yerel siyasetin de merkezi konumunda olduklarından bunların anlaşılabilmesi için yerelde uygulanan siyasetin de bilinmesi gerekmektedir. Yani kentin sorunların çözmesi beklenen yerel siyasetçilerin bu sorunları bilip bilmediği, sorunların giderilebilmesi için alternatifönerilere sahip olup olamadıkları kentli insan yakından ilgilendirmektedir. Günümüzde kentsel sorunlar olarak beliren önemli bazı konular göç, kentleşme, kentlileşme, kentsel yoksulluk, kentsel dönüşüm, kentsel gerilimler ve rant, kent konseyleri-yönetişim ve kent yönetiminde karşılaşılan sorunlar (Liyakat- Ehliyet) olarak sayılabilir. Bu sorunların sayısını artırmak mümkün olmakla birlikte bu araştırma yukarıda sayılan sorunlarla sınırlandırılmıştır. Yerel yönetimlerin sayılan sorunları, kendi imkânlarıyla çözüme kavuşturması arzu edilen bir durumdur. Fakat maddi kaynakların ve insan kaynă̆ının yetmediği sorunlarda merkezi idareden destek alarak sorunların giderilmesi de oldukça sık rastlamılan uygulamalardandır. Bu araştırmada güncel kentsel sorunlar olarak belirlenen konuları çözmek için yasal mevzuat ve düzenlemelerin oldukça yeterli olduğu fakat yerel siyasal aktörlerin etkisi altında olan yerel yönetimlerin uygulamalarmın sorunlarla baş edebilmede çoğunlukla yetersiz kaldı̆̆ı, kent konseyi gibi kurum-

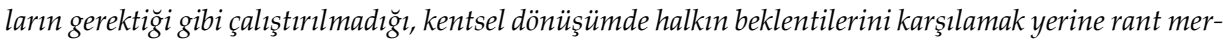
kezli bir yaklaşımın benimsendiği, liyakat ve ehliyetin yerini nepotizm ve kronizmin aldığı ortaya konulmaya çalışılmıştır.

Anahtar Kelimeler: Yerel Yönetimler, Kentsel Hizmetler, Güncel kentsel Sorunlar, 


\title{
The Approach of Local Governments to Current Urban Issues in Turkey
}

\begin{abstract}
In democratic countries, local governments have always had an important place in the governance structure. The election of local government bodies, the fact that they have assemblies representing the city and keeping various channels of political participation open made them indispensable for democracy. Since these institutions are also central to local politics, local politics must be known in order to understand them. In other words, whether the local politicians who are expected to solve the problems of the city knows these problems and whether they have alternative suggestions to solve the problems is closely related to the urban people. Some of the important issues that appear today as urban problems are migration, urbanization, urban poverty, Urban Transformation, Urban Tensions and Surpus, urban councils and governance, and city administration (Merit-Skill). Although it is possible to increase the number of these problems, this research is limited to the problems mentioned above. It is desirable for local governments to solve the problems mentioned by themselves. However, the problems that are not sufficient for human resources and financial resources by receiving support from the central administration is one of the most common applications. In this study, it is seen that the legal regulations and regulations are quite sufficient to solve the issues identified as current urban problems, but the practices of local administrations under the influence of local political actors are often insufficient to cope with the problems, It was tried to put forward that institutions such as the city council were not properly operated, instead of meeting the expectations of the people in urban transformation, a rent-based approach was adopted and merit and competence were replaced by nepotism and chronism.
\end{abstract}

Keywords: Local Govenments, Urban Services, Current Urban Problems 


\section{Giriş}

Yerel yönetimler il, belediye ve köy gibi belirli bir yerleşim yerinde yaşayan vatandaşların temsiline imkân vererek demokrasinin temel değerlerinin yaşatılması ve yaygınlaştırılmasına katkı sağlayan kurumlardır. Bunun yanında, halka en yakın kamu kurumları olarak yerel nitelikli kamusal hizmetleri etkin ve verimli bir şekilde sunma imkânlarına da sahiptirler. Türkiye'de yerel yönetim birimleri 1982 Anayasası hükümlerine göre; il özel idaresi, belediyeler ve köyler olarak zikredilmekle beraber bunlar içerisinde belediyelerin önemi her geçen gün biraz daha artmaktadır. Bu nedenle "yerel yönetim" denildiğinde akla ilk gelen kurum belediyeler olmaktadır.

Yerel yönetimler özellikle de belediyeler kentsel alanlarda yaşayan insanların hayatlarını kolaylaştırmak üzere çeşitli hizmetler üretmektedirler. Fakat üretilen çeşitli hizmetlere rağmen kentte yaşayanlar çeşitli sorunlarla karşı karşıya kalabilmektedir. Bu sorunlara kısaca "Güncel Kentsel Sorunlar" denilebilir. Bunlardan en öne çıkanlar bu araştırmanın konusunu oluşturmaktadır. Paul Peterson (1981, s.75) bir çalışmasında yerel yönetimlerin politik gücünün sinırları olduğunu ifade ederek "Kentler kentsel yaşam hakkında siyasa üretebilirler. Ancak kentteki toplumsal refah düzeyinin artması için bir şey yapamazlar, yerel yönetim birimi; bu konularda yeterli kaynak ancak merkezi (federal) düzeyde sağlanabildiği için hükümete bağıml kalmakta, yoksulluk, kentsel çöküntü alanları ve yüksek suç oranlarn gibi sorunlarla yıllardır uğraşmasına rağmen hiçbir kesin sonuç alınamamaktadır" değerlendirmesinden hareketle yerel yönetimlerin uzun yıllardır üzerinde çalıştığı sorunlar inceleme konusu yapılmıştır.

Bu araştırmada göç, kentleşme-kentlileşme, kentsel yoksulluk, kentsel dönüşüm- kentsel gerilimler ve rant, kent konseyleri-yönetişim ve kent yönetiminde karşılaşılan sorunlar (Liyakat- Ehliyet) güncel kentsel sorun olarak düşünülmüş ve bu konulara odaklanılmıştır. Bu sorunları artırmak elbette mümkündür fakat araştırmanın çerçevesini sınırlandırmak adına bu sorunların irdelenmesi ile yetinilmiştir.

Yukarıya çıkarılan sorunların bir kısmı Peterson'un da ifade ettiği üzere yerel yönetimlerin tek başına üstesinden gelemeyeceği sorunlar olmakla beraber, sorunun çözümünde en önemli paydaş durumundadır. Örneğin göç, dünya ülkelerinin birçoğunun dahi tek başına üstesinden gelemeyeceği küresel bir soruna dönüşmüş durumdadır. Burada yerel yönetimler açısından 
üzerinde durulan konu kente gelen göçmenlerin herhangi bir soruna yol açmadan yerel halk ile birlikte yaşayabilmesi adına neler yapıldığının ve nelerin yapılabileceğinin ortaya konulmasıdır. Aynı şekilde kentleşme de yine yerel yönetimlerin tek başına üstesinden gelebileceği bir sorun değildir. Merkezi yönetimin kentleşme politikaları burada öne çıkmakta ve yerel yönetimlerin görev ve sorumluluk sınırlarını da çizmektedir. Burada yerel yönetimlere düşen, yerel halk için bu sorumlulukların gereği gibi yerine getirilmesidir. Fakat kent konseyleri ve yönetişim, kentsel yoksulluk, kentsel dönüşüm ve rant, yerel yönetimlerde liyakat ve ehliyet gibi başlıklar yerel yöneticilerin bizzat ilgilenerek sorun alanı olmaktan çıkartabilecekleri başlıklardır.

$\mathrm{Bu}$ araştırma literatür taramasına dayalı olup; güncel kentsel sorunların kavramsal bir çerçevesi çizilmiş, ardından kent yönetiminin kente ait sorunların çözümünde oynadıkları roller, sorunların ortaya çıkmasına yol açan etmenler irdelenmiş Son olarak da güncel kentsel sorunların giderilmesine yönelik önerilere yer verilmiştir.

\section{Önemli Bir Güncel Kentsel Sorun Olarak Göç}

Göç, hem göçü veren mekân üzerinde hem de göçü alan mekân üzerinde etkide bulunmaktadır. Konu göç veren yer bağlamında değerlendirildiğinde, göçü veren mekân genç, nitelikli, üretken nüfusunun bir bölümünü kaybetme durumuyla karşı karşıya kalmakta bunun sonucu olarak da ekonomik, toplumsal ve kültürel açıdan bu süreçten olumsuz etkilenmektedir. Konu göçü alan yer bağlamında ele alındığında ise göçün yoğun ve kontrolsüz biçimde gerçekleşmesi durumunda göçü alan mekânın; sosyo-kültürel yapısı, kentin fiziki dokusu, kentte yaşayanların istihdamı ve çalışanların ücretleri üzerinde birtakım olumsuz etkiler meydana gelmektedir.

Türkiye'nin göç güzergâhının kavşak noktalarından biri üzerinde olması kentleri ve yerel yönetimleri göçler konusunda hazırlıklı olmaya ve çeşitli tedbirler üzerinde çalışmaya zorlamaktadır. Türkiye'ye yönelen göçlerin sebepleri değerlendirildiğinde bunlardan en öne çıanı, Türkiye'nin çevresindeki ülkelerde zaman zaman ortaya çıkan çatışmalar ve siyasal kargaşa neticesinde buralarda yaşayan halkların daha güvenli yerlere gitme arzusu içerisinde olmalarıdır. Ayrıca, Türkiye'nin konumu dolayısıyla batılı ülkelere geçiş yapmak isteyen göçmenler için çekici görülmektedir. Bu nedenle göçmenler Türkiye gibi Avrupa'ya sınır olan ülkelere yönelmişlerdir. Göçmenlerin 
Türkiye'ye yönelmesinde etkili olan bir diğer faktör ise, Türkiye'nin komşu ülkelerle kıyaslandığında nispeten ekonomik açıdan daha iyi şartlar sunması sebebiyledir (Deniz, 2014, s.185). Bütün bu nedenler Türkiye'yi ve kent yönetimlerinden sorumlu olan yerel yönetimleri, göçlerin doğurduğu olumsuz sonuçların etkisi altında bırakmıştır.

Küresel bir sorun haline gelen göç hareketlerinde göçün yönü devletlerin büyük kentlerine doğru olmaktadır. Hal böyle olunca da başta anakentler olmak üzere, metropol bölgeler, sanayi tesislerinin ve hizmet sektörünün en önemli merkezi durumunda olan yerler gelmektedir. Türkiye'nin Marmara bölgesi 1990'lardan bugünlere önemli sayıda uluslararası göçmeni kendisine çekmiştir.

Anakentlerde ve metropol bölgelerde yaşayan göçmenlerin gündelik hayatlarının incelendiği bir araştırmada göçmenlerin yerel halkla etkileşimi de ele alınmış ve göçmenlerin İstanbul ve diğer büyük şehirlerde yoğun olarak çalıştıkları işler arasında atıklardan kağıt, plastik toplama işçiliği, lokantalarda ve otellerin yemekhanelerinde bulaşıkçlık, komilik, tezgahtarlık, küçük çaplı ticaret (Hediyelik eşya, enstrüman ve saat satışı vb.), uyuşturucu satışı, fuhuş, bavul ticareti, tekstil işçiliği, halı dokuma işçiliği gibi alanlarda faaliyet gösterdikleri tespit edilmiştir (Toksöz vd., 2012, s.93). Bu verilerde hareketle ifade edilmesi gereken şey, yerel yönetimlerin göçmenlerin faaliyetlerini takip zorunluluğudur.

\section{Yerel Yönetimler ve Göç}

Göçlerin yönü kentler olduğundan göç politikaları ve göçmenlere uygulanacak her bir uygulamada yerel yönetimler aktif roller üstlenmelidir. Fakat yerel yönetimlerin her birisinin bütçeleri ve iş görme kapasitelerinin birbirinden farklı olması yerel yönetimlerin kapasitesinin yetmediği yerlerde merkezi yönetimin desteğine ihtiyaç duyulmaktadır. Bu bağlamda uluslararası göçün hem merkezi yönetimlerin sorumluluğunda hem de yerel yönetimlerin sorumluluğunda olduğu ifade edilebilir. Uluslararası göçün büyük kitleler halinde gerçekleştiği dönemlerde yerel yönetimlerin bu yükün altından kalkmaları oldukça güç olmaktadır. Yerel yönetimler bireylerin gündelik yaşamlarına en fazla temas edebilen yönetim birimleri olmasından dolayı göçmenlerin barınma ve istihdam ihtiyaçları, düşük sosyo-ekonomik profile sahip olmalarından kaynaklanan kentsel yoksulluk-çalışan yoksulluğu sorunu da 
dâhil olmak üzere çeşitli sorunlar, göçmenlerin dinî ve kültürel ihtiyaçları, çok kültürlülüğün yönetilememesinden kaynaklanan uyum sorunları gibi meseleler, büyük ölçüde yerel yönetimlerin yetki ve sorumluluğunda bulunan sosyal ve kültürel hizmetler alanına girdiğinden onlar tarafından çözüme kavuşturulmalıdır (Bahçeci ve Uzun, 2017, s.7).

Yerel yönetimler göçmenler için sadece kendi kaynaklarını kullanmak yerine bireysel bağışları yönlendirmelidir. Bu düzenlemeyi İstanbul da ki yerel idarecilerin bir kısmı gerçekleştirmiştir. Örneğin türü ve miktarı oldukça çeşitli olan bu bağışların Ramazan ayında zirve yaptığı ve yılın geri kalanında düşük düzeyde seyreden döngüsel bir doğası olduğunu Küçükçekmece Belediyesi tarafından ifade edilmiştir (Woods ve Kayalı, 2017, s.17).

Yerel yönetimlerin önümüzdeki dönemde gerçekleştirmesi gereken en önemli çalışma mültecilerle yerel halkın birlikte yaşama kültürünün geliştirilmesine yönelik çalışmalar olacaktır. Şu ana kadar, özellikle belediyeler tarafından yapılan proje ve faaliyetler sadece mültecileri hedef almaktaydı. Bunun yerine aynı sosyoekonomik seviyede bulunan yerel vatandaşların desteklenmesi sağlanmalıdır. Bu sayede toplumda kamplaşma ve çatışmadan uzak durulabilir. Ayrıca ekonomide kayıt dışılık, enformel sektörler başta olmak üzere maaşlarda eşitsizlik, iş güvencesi verilmeden çalıştırma, çocukların çalıştırılması, insancıl olmayan yaşam koşulları, sağlık ve eğitim imkanlarına erişememe, gecekondulaşma, çarpık kentleşme, kentsel güvenlik gibi konuların hem yerel topluluk üzerinde hem de mülteci topluluklar üzerinde büyük problemlere yol açmaktadır. Bu bilinçle, yukarıda sayılan sorunlarla yerel yönetim düzeyinde mücadele çok büyük önem taşımaktadır.

Hem merkezi hem de yerel yönetim ortaklığında mültecilerin demografik dağılımın planlaması ve bu planlama doğrultusunda geliştirilecek faaliyetler neticesinde her bölgede ihtiyaç duyulan insan kaynağına göre yönlendirilmesi önemlidir. Zira mülteciler belli büyükş̧ehirlere yoğunlaşma eğilimindedirler. Oysa iyi bir planlama ile mülteciler Türkiye'nin kalkınması açısından büyük bir destek noktası oluşturma potansiyeline sahiptir.

\section{Kentleşme ve Kentlileşme}

Kentleşmeyi kentlerdeki nüfus birikim süreci olarak açıklamak mümkün olmakla beraber bu tanımın kapsayıcı olduğu ve durumu açıklamada yeteri olduğu söylenemez. Zira kentleşme dünyada son iki yüz yılda yaşanan en 
önemli olgularından birisidir. Sanayi devrimi ile boy gösteren yeni gelişmeler, ticaret ve üretim biçiminde değişiklikler, dünyanın batısında başlayan ve giderek tüm dünyayı etkileyen nüfus hareketliliğine yol açmıştır. Kırsal alanlarda yaşayan büyük miktarlardaki nüfusun kentlere akın etmesi beraberinde gelenekten koparak modernliğe geçişin ilk adımları olarak da görülmektedir.

Kentleşmenin nedenlerini ekonomik, teknolojik, siyasal kararlar ve sosyo-psikolojik nedenler şeklinde sınıflandırmak mümkündür. Sayılan nedenlerin birçoğu Türkiye'nin kentleşmesinde bir arada görülmüştür. Türkiye'de son nüfus sayımına istinaden belirlenen 79.814.871 (TÜİK, 2016) kişilik nüfusun, 73.671 .748 gibi büyük bir kısmının il ve ilçe merkezlerinde, yani kentlerde yaşadığı görülmektedir. Belde ve köylerde yaşayanları, kırsal kesim olarak değerlendirecek olduğumuzda buradaki oranın 2010 yılında Birleşmiş Milletler tarafından hazırlanan raporda Türkiye için yapılan tespitten daha yüksek bir oran olduğunu vurgulamak gerekmektedir. Zira söz konusu raporda 2014 yılı için Türkiye'de kentleşme oranı \%73 olarak öngörülmüştü oysa gerçekleşen oran \% 91,8 olmuştur (Zengin, 2018, s.92).

Türkiye'de izlenen sanayileşme stratejisi neticesinde tarımdan sanayiye nüfus kayması gerçekleşmiş, Fakat Türkiye'de kentsel alanlardaki üst yapı ve altyapı yetersizlikleri kentleşmeyi temel toplumsal sorunlardan biri haline getirmiştir. Bu sorunlu kentleşmenin ardında yatan temel öğe Türkiye'de sanayileşme hızı ile kentleşme hızı arasında bir uyum olmamasıdır. Bunun dişında sanayinin talep ettiği nitelikli işgücünü de sunamayan kırsal kökenli iş gücü, hizmet kesimine kaymak zorunda kalmıştır.

Bir kişi kente geldiğinde kamudan hizmet talep etmekte ve taleplerde kırsal ile karşılaştırıldığında önemli bir patlama yaşanmaktadır. Kente gelenler kamudan öncelikle konut istemekte, iş istemektedir. Bu ihtiyaçları dışında kentte insanca yaşayabilmek adına, evinde düzenli akan su ve kanalizasyon sistemleri, her gün çöpünün alınmasını istemektedir. Bütün bunlar dışında kenti cazip kılan, çekici kılan sosyal imkânlardan, eğitim olanaklarından ve sağlık hizmetlerinden yararlanmak istemektedir.

Sağlıklı bir kentleşme için sosyal donatı alanları ve konut stokunun artırılması büyük önem taşımaktadır. Bu nedenle yerel yönetimlerin bu konu üzerinde çalışmalar yapması gerekir. Fakat konut ile ilgili düzenlemelerde yerel yönetimlerden daha önemli aktör merkezi idarelerdir. Konuta ve dolayısıyla kentleşmeye ilişkin politikalar özel girişimin ağırlıklı olduğu ülkelerde bile, 
merkezi yönetimin etkisi altında ortaya çıkmaktadır. Yerel yönetimlerin konut edindirme yardımlarını ve teşvikleri tek başına hayata geçirmesi oldukça güç olduğundan merkezi idare ile birlikte hareket etmek durumundadır. Başka bir şekilde ifade edilecek olursa bireylerin konut talepleri asıl olarak, kamu hizmetlerinin düzenleyici politikalarının kombinasyonunun bir sonucu olarak ortaya çkmaktadır (Kılıç ve Özel, 2006, s.213).

Yasal düzenlemelerle belediyelere, sağlıklı bir kentsel planlama yapabilme konusunda önemli yetki ve sorumluluklar verilmiştir. Söz konusu görev ve yetkiler değerlendirildiğinde belediyelerin hem kentsel arsa üretiminde hem de konut üretiminin yerel düzeyde gerçekleştirilmesinde tek kurum olduğu söylenebilir (Keleş vd., 1999, s.53). Belediyelerin kentleşmeyi sağlıklı bir şekilde gerçekleştirmesi ve kentsel alanların kentte yaşayanlar için sorun oluşturmaması için bir verilen yetkilerden en önemlisi "imar planları yapma yetkisi" iken diğeri 3194 sayılı İmar Kanunu'nun 18. maddesi 1. fikrasıdır. Bu düzenlemede imar sınırları içinde bulunan arsa ve arazilerin maliklerinin veya hak sahiplerinin muvaffaktı aranmaksızın arsa veya araziler birbirleriyle, kamu kurumlarına ait yerlerle, belediyeye ait yerlerle birleştirmeye valilik veya belediye yetkili kılınmıştır. Ayrıca bu kurumlar gerek görürlerse bunları yeni oluşan imar planı doğrultusunda ada veya parsellere ayırmaya, müstakil, hisseli yahut da kat mülkiyeti esasına göre hak sahibi olanlara dağıtmaya ve resen tecil işlemini yaptırmaya yetkili kılınmıştır. İmar planları uygulamalarında yol, yeşil alan, sosyal tesisler, okul inşaat alanı, muhtarlık büroları gibi alanlar arsa veya arazi sahiplerinden bu bölgelerin artan değeri karşılığında alınan düzenleme ortaklık payı (DOP) ile oluşturulmaktadır. Başka bir ifade ile DOP kesintisi yapılarak yasada sözü edilen kamusal alanlar bir bedel ödemeksizin kamunun kontrolüne geçmektedir. Bu uygulamada düzenlemeye giren tüm Parsellerin yapılaşmaya uygun olabildiğince müstakil imar parseli alması bir kuraldır. İmar Kanunu'nun 18. maddesi uygulamasında uyulması gereken temel kurallar da düzenlenmiştir. İmar uygulamalarının daha sorunsuz uygulanabilmesi yerel yönetimlerin adaleti gözeten yaklaşım içerisinde olması ve merkezi idarenin de imar kanunu yeniden ele alarak özellikle de yargı kararlarının işaret ettiği hususlar paralelinde bir yasa taslağı oluşturulması gerekliliği ifade edilebilir. 


\section{Kentsel Dönüşüm ve Kentsel Rant}

Kentsel dönüşüm kentlerin sağlıklı bir görünüme kavuşması için son yirmi yılda yerel yönetimlerin gündemine giren önemli bir başlıktır. Kentsel dönüşümle kentler, sağlıklı bir kentleşmeye kavuşmak için önemli bir firsat yakalamış durumdadır. Kentsel dönüşüm uygulamalarında kentlerin kültürel kimlik öğelerinin, o kente ait sivil mimari örneklerinin korunması veya onları ön plana çıkaracak yaklaşımların benimsenmesi önemlidir. Günümüzde kent bilimcilerin kentlere ilişkin önem verdiği başat konulardan birisi kentin sahip olduğu tüm değerlerin korunmasıdır ki, bu değerler tüm boyutlarıyla kültürel değerler ve doğal değerler olarak ifade edilebilir.

Dünyada ilk kentsel dönüşüm uygulamaları batının gelişmiş kentlerinde başlatılmıştır. Bu çalışmalar, batının gelişmiş kentlerinde her açıdan (sosyalekonomik) çöküntü alanlarının yeniden canlandırılmasına yönelik müdahaleler yapılmasıyla başlamıştır. Sanayileşmeden etkilenerek hızlanan kentleşme süreci, kentsel mekânlarda işlevsel değişiklikler, kent merkezlerinin yıllar içerisinde yorgun yapı stokları ile dolması, afetler ve savaşlar gibi birçok neden kentlerin dönüşümünü gerekli kılmıştır (Sağır, 2009, s.60).

Türkiye'de kentsel dönüşüm için çok sayıda kanunun çıkarılmış olduğu ifade edilebilir. Bu kanunlardan 6306 Sayılı Afet Riski Altındaki Alanların Dönüştürülmesi Hakkında Kanun ve 5393 sayılı Belediye Kanunun 73. Maddesi yerel yönetimleri hem rahatlatan hem de sorumluluklarını artıran bir özelliğe sahiptir. 5366 sayılı Yıpranan Tarihi ve Kültürel Taşınmaz Varlıkların Yenilenerek Korunması ve Yaşatılarak Kullanılması Hakkında Kanun ise hem merkezi idarenin taşra teşkilatlarını hem de yerel yönetimleri harekete geçirmesi açısından önemlidir. Diğer kanunlar ise: Gecekondu Kanunu, 2981 Sayılı İmar ve Gecekondu Mevzuatına Aykırı Yapılara Uygulanacak Bazı işlemler ve 6785 Sayılı İmar Kanununun Bir Maddesinin Değiştirilmesi Hakkında Kanun, Toplu Konut Kanunu, Kuzey Ankara Girişi Kentsel Dönüşüm Projesi Kanunu ve İmar Kanunu olarak sayılabilir. Her ülkenin kentsel dönüşümü gerektiren faktörleri farklılıklar arz eder. Türkiye'de en öne çıan faktör depremler olmakla birlikte gecekondu alanlarından, çöküntü alanlarından kentin temizlenmesi de önemli faktörler arasındadır.

Depremler nedeniyle kentsel dönüşümün gecikilmeden gerçekleştirilmesi gereğini 17 Ağustos 1999 depremiyle fark eden merkezi ve yerel idareler çalışmalara başlamıştır. Ülke ekonomisini yaklaşık olarak 16 milyar dolar gibi 
büyük bir yükle karşı karşıya bırakan Marmara depremleri, toplumsal psikolojimizi derinden sarsmış ve ülkemizin en doğusundan en batısına, en kuzeyinden en güneyine kadar bu coğrafyada yaşayan herkesi değişik ölçülerde etkilemiştir.

Depremlerin yıkıcı etkilerinin fazla olmasının temel nedeni özellikle büyük kentlerde yapıların bir kısmının mühendislik hizmeti almadan kaçak olarak inşa edilmiş olmasıdır. Büyükşehirlerdeki yapıların bir kısmının da mühendislik hizmeti almış olsa bile denetim yapılmadan inşa edildikleri için, imarlı veya imarsız, ruhsata aykırı yapılardan kaçak kentsel alanlar oluşmuştur.

Kentsel dönüşümle birlikte zikredilmesi gereken önemli bir kavram da kentsel rant kavramıdır. Kentsel topraklarda rant, farkllık rantı, konum rantı veya erişebilirlik rantı olarak tanımlanmaktadır. Kent merkezine en uzak noktadaki kentsel topraklar en az değerli topraklar, merkeze en yakın noktadaki kentsel topraklar da en değerli topraklar olmaktadır (Meydan ve Emür, 2013, s.55).

Bu rantın cazibesi çoğu kez yerel yönetimler ve özel teşebbüsler kentsel dönüşüme yönlendirmekte ve vatandaş istekleri ikinci plana atılabilmektedir. Kentsel toprak rantı ülkemizde siyasal yatırım aracı olarak ortaya çıkışı başta gecekondu afları olmak üzere çeşitli dönemlerde çıarılan imar afları ile gerçekleşmiştir. Kentsel rantları ortaya çıkaran diğer faktörler incelendiğinde ikinci sırada imar planlarının geldiğini ifade etmek gerekir. İmar planlarına ilişkin yaşanan en önemli sorunlardan biri belediye başkanlarının imar düzenlemeleri üzerindeki etkisidir. Bu konuda Çebi, "belediye başkanları adeta yarı tanr gibiler, dedikleri dedik. İki dudağı arasından çıkanlar yapılması gerekenler ve kitabına uydurulması gereken işlerdir" (2016, s.101) değerlendirmesini yapmış, Turgut Cansever ile yapılan bir görüşmede ise Cansever kentlerdeki konut planlaması ve arzı konusunda yerel yönetimleri eleştirerek, "Bakın, Türkiye'de meclis üyelerinin hepsi istisnasız emlak komisyoncusu. Hal böyle olunca şehir hakkında söz söyleme imkanı kalmıyor" (Can ve Doğan, 2015, s.87) değerlendirmesi kentteki konut rantının paylaşımına ilişkin fikir vermektedir.

\section{Kent Yoksulluğu}

Yoksullukla ilgili yapılan çalışmalarda yoksulluk; mutlak- göreli yoksulluk, objektif- sübjektif yoksulluk, gelir yoksulluğu- insani yoksulluk ve kırsalkentsel yoksulluk şeklinde bir ayırıma tabii tutulmaktadır. 
Yoksulluğun nedenleri açısından konu değerlendirildiğinde, bütün çalışmalarda ortak başlıklar, eğitim yetersizliği, ekonomik yetersizlik, yaşlılık, engellilik, herhangi bir mesleki alan üzerinde beceri kazanamamış olmak, eski hükümlü olmak gibi nedenler mikro nedenler olarak görülürken; dengesiz ve bozuk bir ekonomik yapı, işsizlik, dengesiz gelir dağılımı, siyasal ve ekonomik istikrarsızlıklar, afetler, yolsuzluklar, savaş durumu vb. nedenler makro nedenler olarak sayılmaktadır.

Dünyanın birçok ülkesinde uygulamaya sokulan neoliberal uygulamalar neticesinde yoksulluk ve onun yarattığı sorunlar giderek ağırlaşmaktadır. Bu sorunların en yoğun yaşandığı alanlar ise kentsel alanlardır. Kentsel alanlarda yoksulluğun artmasının yanı sıra çeşitlenmiştir. Bu artış ve çeşitlenme neticesinde "Kent Yoksulları" kavramı, 1996 yılı Birleşmiş Milletler HABİTAT raporunda kendisine yer bulmuştur. Söz konusu raporda, kentsel yoksulluk; Nüfusun kentlerde yaşayan bir kesiminin, çeşitli nedenlerle, tarihsel ve coğrafi olarak belirlenmiş asgari bir geçim standardını sağlayabilecek yeterli kaynaklara ve konuta ulaşamaması, barınma yoksulluğu ile beraber davranışsal ve toplumsal ilişkiler açısından sorunlara yol açabilecek bir konumda olması durumu olarak açıklanmıştır (Batmaz, 2016, s.40).

Kentlerde yaşayan yoksulların sorunlarının çözülmesi hususunda, son süreçte oluşan algı, sorumluluk merciinin devletten topluma doğru kaydığını göstermektedir. Böylece yoksullukla mücadelede devlet- yoksul vatandaş ilişkisinin boyutu değişerek yoksul vatandaş- STK'lar ve yoksul vatandaşdurumu iyi olan vatandaşlar şekline dönüşmüştür (Buğra, 2008, s.239). Yoksullukla mücadele devletin değil toplumun görevidir şeklinde bir yaklaşımın çok sağlıklı olmadığı fakat devlet- toplum işbirliğinin sorunu daha kapsamlı bir şekilde ele alabileceği görülmelidir.

Yerel yönetimlerin yoksullukla ilintili problem çözümüne dâhil edilmesi 1960'lı yılların ortalarından itibaren gerçekleşmiştir. Yerel yönetimler, Avrupa ülkelerinde yardım programı ve sosyal kalkınma projeleriyle yoksulluk sürecine entegre edilmişlerdir.

Türkiye'de ise kent yoksullarının sorunlarının çözümü bağlamında yerel yönetimler yasal mevzuat çerçevesinde yürürlükteki 5393 sayılı Belediye Kanunu, 5216 sayılı Büyükşehir Belediye Kanunu ve 5302 sayılı İ Özel İdaresi Kanunu kapsamında görevli kılınmışlardır. Ayrıca yoksullukla mücadele için merkezi yönetimin yerele aktarmakta olduğu mali kaynaklar da yerel yö- 
netimler tarafindan kullanılmaktadır. Sayılan yasaların haricinde 2012 yılında gündemimize giren 6360 sayılı yasayla da belediyelere yeni birtakım görevler verilmiştir. Sağlık hizmetleri, gezici sağlık üniteleri ile yetişkinlere, yaşlılara, engellilere, kadınlara, gençlere ve çocuklara yönelik her türden sosyal ve kültürel hizmetleri yürütmek ve geliştirmek, bu amaçla sosyal tesisler kurmak, meslek ve beceri kazandırma kursları düzenlemek, işletmek ya da işlettirmek, bu hizmetlere ilişkin üniversiteler, kamu kurumları ve sivil toplum örgütleri ile işbirliği yapmakla görevli kılınmışlardır. Bunun dışında belediye başkanı dahi, bütçede yoksul ve yaşlılar için ayrılan ödeneği kullanmak, özürlülerle ilgili faaliyetler için özürlü merkezleri oluşturmakla görevli k1lınmıştır.

Kentsel yoksullukla mücadele için kentin bütün yerel kurumlarının ortak strateji geliştirme ve kentteki kamu kurumları arasındaki koordinasyonun geliştirilmesi gerekir. Bu nedenle, kentleri çok daha iyi tanıyan belediyelere verilen yetkilerin yanında mali olanakları da olabildiğince artırılması önem taşımaktadır. Mevcut durum itibariyle, belediyelerin yoksulluğu önleme ve azaltma konusunda yeterli olduklarını söylemek güçtür. Yoksulluk sadece o yörede yaşayan insanların değil toplumun ortak sorunudur, bu sorun da hem yerel hem de ulusal düzeyde ele alınarak çözüme kavuşturulabilir (Hazman, 2010, s.135).

\section{Yerel Yönetişim ve Kent Konseyleri}

Yerelde alınan kararlara katılım anlamında yaygın olarak kullanılan kavramlardan biri yönetişimdir. Bu kavram uluslar arası kuruluşlar ve özellikle Birleşmiş Milletler, Dünya bankası, IMF ve OECD gibi kuruluşlar tarafından yayınlanan raporlarda da sıklıkla kullanılmıştır. Bu metinlerde genelde "iyi yönetişim" olarak ifade edilen kavram, "bir ülkedeki ekonomik, siyasal ve idari otoritenin her düzeydeki işlemleri yürütülmesi sürecinde vatandaşlarm ve toplumsal gruplarm kendi çıkarlarmı korumak ve yasal haklarım kullanmak için gerekli mekanizmalara ve kurumlara sahip olmaları" şeklinde kavramsallaştırılmıştır.

Yönetişimin üç boyutunun bulunduğu ve bunların devlet (yerel yönetim), özel sektör ve sivil toplum olduğu ifade edilebilir ayrıca bu aktörlerin her birinin kendine özgü rolleri olduğu da söylenmelidir.

Günümüz yerel yönetimlerinin en anahtar kavramlarından birisi durumunda olan yönetişim, yönetimden farklı olarak, hiyerarşik ilişki düzeyini 
kabul etmeyen bir yaklaşıma sahiptir. Yönetişimin hâkim olduğu yerlerde hiyerarşi yerine, heterarşik ilişki vardır. Yani, yönetişimde karşılıklı ilişki ve bağımlılık halindeki faaliyetlerin eşgüdümünü ve kendi kendini organize eden kişiler arası ağları, örgütler arası eşgüdümü ve sistemler arası döngüyü içeren bir yaklaşım vardır.

Açılamalardan da anlaşılacağı üzere yönetişim, idareden halka doğru veya yukarıdan aşağı doğru tek yanlı bir yönetim tarzı yerine birlikte yönetmeyi öngören bir sistem olarak uluslararası kuruluşlarca hararetle önerilen bir yaklaşımdır. Katılımcılığı önermesi dolayısıyla sivil toplum kuruluşlarının ve özel kesimin de yönetime, karar almadan denetime kadar her aşamada katılması, kavramın temelini oluşturmaktadır (Yılmaz, 2001, s.7).

Ancak literatürde katılım noktasında çeşitli sorunlar olduğu belirtilmektedir. Bu sorunların kaynağı birçok çalışmada halkın katılım istediğine engel olan unsurlar üzerinden olmuştur. Ancak katılım sürecinin etkin bir şekilde gerçekleşebilmesi için belediye personelinin ve idarecilerin bu sürece uyum sağlaması gerektiği Tunç ve arkadaşları tarafından yapılan "Yerelde Yönetişim Algısı Üzerine Bir Alan Araştırması: Kahramanmaraş Büyükş̧ehir Belediyesi Örneği" başlıklı çalışmada ortaya konulmuştur (2019:269).

Kent Konseyleri uygulaması, 5393 sayılı Belediye Kanunu ile yönetişim yaklaşımı doğrultusunda sivil toplum örgütlerinin, meslek teşekküllerinin ve diğer aktörlerin karar ve uygulamalarda yer alabilmesi amaciyla getirilmiş önemli bir düzenlemedir. Yerel yönetimlerin anahtar kavramlarından olan "katılım" konusu yönetişim ve kent konseyleri ile birlikte değerlendirildiğinde anlam kazanmaktadır. Fakat uygulamaya bakıldığında 5393 sayılı kanunda her ne kadar "kent konseyi kararlar belediye meclisinin ilk toplantısinda gündeme alınıp değerlendirilir" yaklaşımı benimsenmiştir. Fakat belediye meclis gündemini belirleme yetkisinin belediye başkanına ait olması ve başkanın aynı zamanda belediye meclisinin üzerinde önemli bir nüfuza sahip olması, kent konseylerini görünürde bir yönetişim yapılanmasının ötesine geçemeyen organ haline getirmiştir.

Bunun dışında, kent konseylerinin bütçelerinin mevzuat gereği belediye inisiyatifinde bulunması bir diğer sorun alanıdır. Zira bu durum kent konseylerinin bağımsız karar alıp alamadığı hususunu tartışılmalı hale getirmektedir. 
Yerel yönetimlerin gerçek manada bir yönetişim mekanizması kurmada dikkat etmesi gereken hususlardan birisi kent konseylerine müdahale etmemek ve kent konseylerinden gelen teklifleri önemsemektir. Aksi durum yönetişim olmayacaktır.

\section{Yerel Yönetimlerin Yönetim Sorunu (Liyakat ve Ehliyet Sorunu)}

Yerel yönetimler, merkezi idarenin yasa ile belirlemiş olduğu kurallar çerçevesinde personelini özgürce oluşturabilir. Merkezi idarenin personelle ilgili en önemli düzenlemesi ise Liyakat ve ehliyete ilişkin olan düzenlemedir. Zira kentte yaşayan her bir insanın yerel yönetimlerden talep ettiği hizmetleri tam ve sağlıklı bir şekilde alabilmesi liyakat ve ehliyet sahibi personelle hizmet verilip verilmediği ile yakından ilişkilidir.

Yerel yönetim hizmetlerinin kamu hizmeti olmasından dolayı bu hizmeti verenlerin kamu hizmeti görevine alınmalarında iki farklı sistemden söz edilebilir. Yönetim literatüründe bu sistemlerden biri "liyakat sistemi" diğeri ise kayırma sistemi olarak ifade edilmektedir. Liyakat, Devlet Memurları Kanunu'nun (657 sayılı) 3. maddesinin C bendinde ele alınmıştır. Söz konusu düzenlemeye göre liyakat "Devlet kamu hizmetleri görevlerine girmeyi, sinuflar içinde ilerleme ve yükselmeyi, görevin sona erdirilmesini liyakat sistemine dayandırmak ve bu sistemin eşit imkânlarla uygulanmasında devlet memurlarm güvenliğe sahip kılmaktır" şeklinde ifade edilmiştir.

Liyakat sistemi toplumun moral değerlerine dayanmakla beraber kamu hizmeti görenlerin saygınlığını ve güvenliklerini de artırmaktadır. Bu sistem sayesinde kamu kurumları kayırma, patronaj ilişkileri, partizanlık gibi uygulamaların olumsuz sonuçlarından da kurtarılmış olmaktadır. Zira liyakat sistemi bilgi, zekâ, karakter, enerji gibi değerleri öne çıkarmaktadır (Eroğlu, 1972, s.229).

Devlet Memurları Kanunu ile benimsenen ve kamu personel hukukunun ilkelerinden olan liyakat ilkesi kamu yönetimi ve yöneticilerine güveni tesis eden en önemli ilkelerden biridir. Liyakat ilkesinin zıddı olan kayırma ya da ganimet usulünde kişiler memuriyete siyasi partilerle ilişkileri, yakınlıkları veya o partilere hizmetleri esas alınarak atanmaktadırlar. İktidarı ele geçiren siyasi parti, ekibini kendi taraftarları arasından kurmakta, süresi dolduğunda da kurmuş olduğu ekibiyle birlikte yönetimden ayrılmaktadır (Bucaktepe, 2014, s.469). 
Liyakat ile birlikte düşünülen başlıklardan birisi de ehliyet kavramıdır. Ehliyet; herhangi bir konuda somut şartları sağlamış, örgün veya örgün olmayan eğitim gibi hazırlıkları bitirmiş, kabul edilebilir niteliklere ulaşılmış hali gösterir. Bu anlamda bilgi ve beceri yeteneğini anlatır. Kamu veya özel sektör istihdam politikalarında ilk yapılan işlerden biri adaylardan beklenen niteliklerin saptanarak duyurulmasıdır. Ehliyet şartları adayların belirli bir seviyeyi sağlayabilmesini, yani nitelikleri itibarıyla ilk elemeden geçmelerini sağlar.

Bir kurumda herhangi bir statüde çalışan ehliyetsiz ve liyakatsiz personel kurumu için önemli bir tehdit unsurudur. Bu durum yönetici sınıflarda ortaya çıktığında ise sorun katlanmakta liyakatsiz bir yönetici kurumun yıllar içinde oluşturduğu birikimi yerle bir edebilmektedir. Belediyelerde partizan yaklaşımlar ve diğer saiklerle liyakatsiz yöneticilerin her dönem görev yaptığı bilinmektedir. Bu yaklaşımlardan en öne çıkanı ise Nepotizm ve Kronizmdir. Nepotizm, yönetim literatüründe akraba kayırmacılığ şeklinde ifade edilmektedir. Bu bağlamda Nepotizm, bir bireyin sadece iktidar ve güç sahibi kişilerle akrabalık ilişkilerinin temel alınmasıyla göreve alınması veya görevde yükseltilmesi şeklinde tanımlanabilir (Özler vd., 2007, s.438). Kişinin yöneticiye akraba olduğu için liyakat ve ehliyet gibi ilkelere sahip olup olmadığı dikkate alınmadan göreve alınması yerel halkın siyasal sisteme olan güvenini olumsuz yönde etkileyecektir. Bezer durum "kronizm" için de geçerlidir. Kronizm ise literatürde kamuya personel alımlarında ve yükselmelerde liyakat (yeterlilik), eşitlik, hakkaniyet, objektiflik gibi kıstaslar yerine daha çok eş dost odaklı ilişkilerin esas alınması kapsamında değerlendirilmektedir. Bu bağlamda bu tanımlama; eş-dost kayırmacılığı şeklinde ifade edilmektedir (Gönülaçar, 2014, s.10). Kronizmin, yerel yönetimlerde yönetici atamalarında sıklıkla karşılaşılabilen bir durumu yansıttığı ifade edilebilir. Bu bağlamda atamaya yetkili pozisyonlarda bulunan siyasal güç sahipleri, kendilerine yakın buldukları eş ve dostlarını objektiflik ve hakkaniyet ilkelerini bir kenara bırakarak yönetici pozisyonlarında görevlendirebilmektedirler.

İşte burada sorulması gereken en temel soru, atama yapılan kurum benim işletmem olsaydı hatıra binaen bu atamayı yapar mıydım? Ya da böyle bir atama büyük holdinglerde olsaydı sonucu nasıl olurdu? Olmalıdır. Tecrübe ve birikim her zaman önemsenmeli, konu benim bürokratım ya da onun bürokratı boyutuna indirgenmeden ele alınmalıdır. Belediyelerde her seçim döneminden sonra görülen ve artık kanıksanan bu yaklaşım yerine, oturduğu koltuğa yük 
olmayan ve koltuğa güç veren yöneticilerin değiştirilmeden devam ettirilebilmesidir. Aksi hal uzun vadede hizmet alanlar açısından ciddi sorunlar oluşturmaktadır.

Liyakate ilişkin Devlet Memurlar Kanunun getirdiği düzenlemeyi ve kamu personel sınavinda başarılı olanların istihdam edilmesine yönelik uygulamayı bay pas etmek isteyen belediyeler İstisnai Memuriyet Kadrosu Olan Özel Kalem Müdürlüğüne atanan kişilerin, bir süre sonra sınavsız olarak, sinavla girilebilecek memur kadrolarına naklen atama yolunu sıklıkla kullanmakta.

“İstisnai memurluklar” 657 sayılı Devlet Memurları Kanunu'nun 59'uncu maddesinde belirtilmiş ve bunların içinde Özel Kalem Müdürlükleri de sayılmıştır. "İstisnai memurluklara atanmada aranacak şartlar" başlıklı 60'ıncı maddesinde ise istisnai Devlet memurluklarına 48 inci maddede yazılı genel şartları taşıyan kimselerden atanmalar yapılabilir." Denilmektedir. Ayrıca, özel kalem müdürlüğüne atanacakların öncelikle belediyede çalışan memurlar ile diğer kamu kurum ve kuruluşlarında çalışan memurlar arasından seçilmesinin esas olduğu, özel kalem müdürlüğüne yapılacak açktan atamanın ise İçişleri Bakanlığının izni ile yapılabileceği ifade edilmiştir.

Belediyelere ilişkin hazırlanan Sayıştay raporları bu uygulamanın yanlışlığına atıfta bulunulmuş ve Devlet Memurları Kanunu' nun 59'uncu maddesi kapsamında tanınan atama yetkisinin sınırsız bir yetki olmadığı zikredilmiştir. Sayıştay raporlarında; söz konusu yetkinin memuriyete sınavsız girişin bir yolu gibi kullanılmasının hukuken imkan dâhilinde bulunmadığını belirtmiştir. Bu nedenle özel kalem müdürlüğü kadrolarına atanacakların seçiminde, belediye başkanlarının bir seçim dönemi boyunca çalışabilecekleri ehliyet ve liyakat sahibi kişileri seçmelerinin esas olduğunun altı önemle çizilmiştir (Sayıştay, 2017, s.19).

Yerel yöneticilerin birçoğu tarafından kullanılan bu yöntem anayasanın kişilerin kanun önünde eşit olması ve kamu hizmetlerine girmede eşitlik ilkelerini bozucu mahiyettedir. İstisnai memuriyet kadroları sadece hizmetin gereği olarak kullanılması gerekirken, yerel idarecilerin birçoğu tarafından devlet memurluğuna girmede esas olan sınav sistemini aşmaya yönelik olarak kullanılmaktadır. Bu yolla devlet memuru yapılanlar, liyakat esasına uymadığından ve bu kadroların gerektirdiği niteliklere sahip bulunmadığından yerel yönetimlerin ihtiyacı olan nitelikli iş gücü sağlamanın da önünde bir 
engeldir. Bu tür atamaların uygulama ve sonuçları bakımından Hazine menfaatlerini zarara uğratıcı nitelikte bulunduğu da ayrıca ifade edilmesi gereken konulardandır. Sayıştay konuya ilişkin raporlarını TBMM'ye sunmuştur. Bu raporlardan birinde sadece Sincan belediyesinde 2014-2017 yılları arasında bu şekilde özel kalem müdürlüğü kadrosuna atandıktan sonra başka çeşitli bakanlıklara nakil yolu ile giden 7 kişinin bulunduğu tespit edilmiştir.

\section{Sonuç}

Anayasa'nın 127 maddesinde Mahalli idareler; il, belediye veya köy halkının mahalli müşterek ihtiyaçlarını karşılamak üzere kuruluş esasları kanunla belirtilen ve karar organları, gene kanunda gösterilen, seçmenler tarafından seçilerek oluşturulan kamu tüzel kişileri olarak ifade edilmiştir. Bu tanımdan ortay çıkan en temel tespit, yerel yönetimlerin "mahalli müşterek ihtiyaçların karşılanması" amacına dönük çalışmalar yapmasıdır. 6360 sayılı yasa ile büyükşehir olan illerde belediyeler, özel idarelerin kapatılması ve köylerin mahalleye dönüştürülmesinden sonra ekonomik durum ve nitelikli iş gücü bakımından daha güçlü bir duruma gelmişlerdir. Bu halde belediyeler yerel halkın mahalli müşterek ihtiyaçlarını karşılayan, kentsel alanlarda kenttaşların karşılaştıkları sorunları tam ve zamanında çözmesi gereken kurumlar olarak öne çıkmaktadır.

Belediyelerin güncel kentsel sorun olarak kentlilerin gündemine giren sorunları çözebilecek maddi imkânlara ve insan kaynağına sahip olmadığı sıklıkla ifade edilen bir durumdur. Hizmetlerin tam ve zamanında gerçekleştirilemeyişini açıklamaya çalışan bu iki gerekçe hem akademisyenler hem de yerel idareciler tarafından sürekli dile getirilmekte ve merkezi yönetim bu konuda eleştirilmektedir. Oysa bu araştırmada dile getirilen güncel kentsel sorunların büyük bir çoğunluğu işini bilen ve çözümü yerelde arayan yöneticiler için üstesinden gelinemeyecek sorunlar değildir. Dolayısıyla yerel yönetimler yerel halkın karşılaştığ sorunlara çözüm üretmeyi öncelikli olarak kendi yöneticilik becerileri ve kurumsal yapıları içerisinde, yerel halkla bilgi paylaşımı yaparak, kentsel sorunların çözümünde paydaşlarla bilgi paylaşımı yaparak, proje bazlı yönetimsel becerileri geliştirerek, meşru ve kabul edilebilir kaynaklar yaratarak gerçekleştirmek zorundadırlar. 
Merkezi idarenin sürekli desteklediği ve kaynak aktardığı bir yerel yönetim birimini yönetmek sadece idare etmektir. Günümüz insanı halkliya beraber çalışan, onu çözümün bir parçası olarak gören karşılaştığı sorunlar için öneriler paketi olan, yerel halka tepeden bakmayan, demokrasiyi sadece seçim zamanlarında hatırlamayan ve seçmeni "seyirci demokrasisinin" bir aygitı, olarak görmeyen, ehliyet ve liyakate önem veren yerel yönetim birimleri arzu etmektedir. 


\title{
EXTENDED ABSTRACT
}

\section{The Approach of Local Governments to Current Urban Issues in Turkey}

\author{
Murat Sezik \\ İnönü University
}

Local governments, especially municipalities, produce various services to make life easier for people living in urban areas. However, despite the various services produced, people living in the city can face various problems. These problems can be briefly called "Current Urban Problems". The most prominent of these are the subject of this research.

In this study, migration, urbanization, urban poverty, urban transformation, urban tensions and rent, city councils, governance and problems encountered in urban management (Merit) were considered as current urban problems and focused on these issues.

It is of course possible to increase these problems, but in order to limit the scope of the research, these problems have been solved by examining these problems.

\section{Migration as a Major Current Urban Issue}

Migration has an impact both on the place that gives the migration and on the place that receives the migration. When the subject is evaluated within the context of the migrant place, the migrant place faces the situation of losing part of its young, qualified, productive population, and as a result, it is adversely affected by this process economically, socially and culturally. When the subject is addressed in the context of the area receiving the immigration, in case the immigration takes place in an intense and uncontrolled manner, the place receiving the immigration; There are some negative effects on the socio-cultural structure, the physical texture of the city, the employment of the people living in the city and the wages of the employees.

In migration movements, which have become a global problem, the direction of migration is towards the big cities of the states. When this is the 
case, metropolitan areas, especially the metropolitan areas, are the most important centers of industrial facilities and the service sector. Turkey's Marmara region from the 1990s to today, a significant number of international migrants are attracted to it.

Since the direction of migration is cities, migration policies and local governments should take active roles in each application to be applied to migrants. However, the support of the central government is needed in places where the local governments are not capable of having different budgets and business capacities. In this context, it can be stated that international migration is both the responsibility of central governments and local governments.

\section{Urbanization}

Although it is possible to explain urbanization as the population accumulation process in the cities, this definition cannot be said to be inclusive and sufficient to explain the situation. Because urbanization is one of the most important cases experienced in the last two hundred years in the world. New developments, changes in the way of trade and production, which emerged with the industrial revolution, led to population mobility, which started in the west of the world and gradually affected the whole world. With legal regulations, municipalities have been given important powers and responsibilities to make a healthy urban planning. When these duties and powers are evaluated, it can be said that municipalities are the only institutions in both urban land production and local realization of housing production.

\section{Urban Transformation and Urban Rent}

Urban transformation is an important topic that has been on the agenda of local governments in the last two decades for cities to have a healthy appearance. With urban transformation, cities have had an important opportunity to achieve a healthy urbanization. In urban transformation practices, it is important to protect the cultural identity elements of the cities, examples of civil architecture of that city or to adopt approaches that will bring them to the fore. An important concept to be mentioned with urban transformation is the 
concept of urban rent. In urban lands, rent is defined as differential rent, location rent or accessibility rent. Urban soils at the furthest point to the city center are the least valuable soils, and urban soils closest to the center are the most valuable soils. The attraction of this rent often leads local governments and private enterprises to urban transformation, and citizen requests can be put to the fore.

\section{Urban Poverty}

In order to combat urban poverty, it is necessary to develop a common strategy of all local institutions of the city and to develop coordination between public institutions in the city. For this reason, it is important to increase the financial opportunities as much as possible besides the authorities granted to the municipalities who know the cities much better. As of the current situation, it is difficult to say that municipalities are sufficient to prevent and reduce poverty.

\section{Local Governance and City Councils}

Governance is one of the commonly used concepts in terms of participation in local decisions. This concept has also been used frequently in reports published by international organizations and organizations such as the United Nations, World Bank, IMF and OECD. Governance, which is one of the most key concepts of today's local governments, has an approach that does not accept the level of hierarchical relationship unlike the administration. One of the issues that local governments should pay attention to in establishing a real governance mechanism is not to interfere with the city councils and to consider the proposals from the city councils. Otherwise, there will be no governance.

\section{Management Problem of Local Administrations (Merit Problem)}

In management literature, one of these systems is referred to as "merit system" and the other as favorit system. The merit system is based on the moral values of the society and increases the reputation and security of those who receive public service. Thanks to this system, public institutions are saved 
from the negative results of practices such as favoritism, patronage relations and partisanship.

Municipalities seek to bypass the regulation introduced by the Civil Servants Law on Merit and the practice of employing those who pass the public personnel exam. One of them frequently uses the way of assigning the persons appointed to the Directorate of Private Items, which has an Exceptional Officer Staff, to the civil servant positions that can be entered with an examination after a while.

\section{Conclusion}

It is frequently stated that municipalities do not have the financial means and human resources to solve the problems that are on the agenda of the citizens as the current urban problem. These two reasons, which try to explain the full and timely delivery of the services, are constantly expressed by both academicians and local administrators and the central government is criticized in this regard. However, the vast majority of current urban problems expressed in this research are not problems that cannot be overcome for managers who know their jobs and seek solutions locally.

\section{Kaynakça / References}

Bahçeci, I. H., ve Uzun, Ş. (2017). Türkiye'de uluslararası göç ve yerel politika. Yüzüncü Yıl Üniversitesi Sosyal Bilimler Enstitü Dergisi. 4(Özel Sayı), 117

Bucaktepe, A. (2014).Devlet memurluğu ve memurların değerlendirilmesi üzerine düşünceler. Gazi Üniversitesi Hukuk Fakültesi Dergisi, 18, 459-489.

Buğra, A. (2008). Kapitalizm, yoksulluk ve Türkiye'de sosyal politika. İstanbul: İletişim Yayınları

Batmaz, N. Y. (2016), kentsel yoksullukla mücadelede belediyelerin Rolü: Keçiören Belediyesi örneği. Aksaray Üniversitesi İktisadi ve İdari Bilimler Fakültesi Dergisi, 8(1),s.37-50.

Can, A. ve Doğan M. (2015). Bir şehir kurmak, Turgut Cansever'le konuşmalar. İstanbul: Klasik Yayınları

Çebi,A. (2016). Merhametli şehirler. İstanbul: Akıl Fikir Yayınları

Deniz, T. (2014). Uluslararası göç sorunu perspektifinde Türkiye. Türkiye Sosyal Araştırmalar Dergisi, 18, 175-204. 
Eroğlu, H. (1972). İdare Hukuku dersleri. Ankara: Kardeş Matbaası Gönülaçar, Ş. (2014). İnsan kaynakları yönetiminde kayırmacılık kuşatması ve liyakatsizlik çıkmazı. https://www.academia.edu adresinden erişilmiştir.

Hazman Gürler, G. (2010). Kentsel yoksulluk sorunu ve belediyelerin rolü. Türk İdare Dergisi, 467, 135-152.

Keleş, R. (1996). Kentleşme politikası. 3. Baskı, Ankara:İmge Kitabevi.

Kılıç, S. ve Özel, M. (2006). Yerel yönetimlerin konut politikaları üzerine bir inceleme :Çeşitli ülke deneyimleri ve Türkiye. Ç.Ü Sosyal Bilimler Enstitüsü Dergisi, 15(1), 201-228

Meydan, S. G. ve Emür, S. H. (2013), Kentleşme ve Kentsel Rantİlişkisi: Kayseri örneği. Çağdaş Yerel Yönetimler, 4(22), 51-73.

Özler, H. vd. (2007). Aile işletmelerinde nepotizmin gelişim evreleri ve kurumsallaşma. Selçuk Üniversitesi Sosyal Bilimler Enstitüsü Dergisi,17, 437-450.

Peterson, P. (1981). City limits. Chicago Universty Press

Sağır, A. (2009) Kentsel dönüşümlerden sosyal değişmelere: Pendik Belediyesi örneği. Akademik İncelemeler Dergisi, 4(2), 57-80

Sayıştay. (2017). Ankara Sincan Belediyesi Sayıştay Düzenlilik Denetim Raporu.

Toksöz, G. vd.(2012). Irregular labour migration in Turkey and situation of migrant workers in the labour market. Ankara: IOM

Tunç, A, Belli A. vd.(2019). Yerelde yönetişim algısı üzerine bir alan araştırması: Kahramanmaraş Büyükşehir Belediyesi örneği, Gaziantep University Journal of Social Sciences, 18(1), ss.256-270

Tümtaş, M. W. ve Kayall, N. (2017). Suriyeli topluluklarla etkileşim: İstanbul'daki yerel yönetimlerin rolü. İstanbul politikalar Merkezi, Sabancı Üniversitesi.

Yılmaz, O. (2001). Kamu yönetimi reformu. Ankara: DPT Yayınları

Zengin E. Ç. (2018). Kent ve kentleşme sarmalında Türkiye. Kastamonu Üniversitesi İktisadi ve İdari Bilimler Fakültesi Dergisi, 20(1), 84-10.

\section{Kaynakça Bilgisi / Citation Information}

Sezik, M. (2020). Türkiye 'de Yerel Yönetimlerin Güncel Kentsel Sorunlara Yaklaşımı. OPUS-Uluslararası Toplum Araştırmaları Dergisi, xx(xx), 1540-1562. DOI: 10.26466/opus.669211 